Scientific paper

\title{
Reaction between Chromium(III) and EDTA Ions: an Overlooked Mechanism of Case Study Reaction of Chemical Kinetics
}

\author{
Janez Cerar \\ Faculty of Chemistry and Chemical Technology, University of Ljubljana, Večna pot 113, SI-1000 Ljubljana, Slovenia. \\ *Corresponding author: E-mail: janez.cerar@fkkt.uni-lj.si
}

Received: 05-03-2015

Dedicated to prof. Jože Koller on the occasion of his $70^{\text {th }}$ birthday.

\begin{abstract}
Widely cited and accepted explanation of reaction mechanism of the case study reaction of chemical kinetics between $\mathrm{Cr}$ (III) ions and ethylenediaminetetraacetic acid (EDTA) contradicts modern chromium(III) coordination chemistry data. Absorption UV and visible light spectra were recorded during the reaction between aqueous solution of $\mathrm{Cr}\left(\mathrm{NO}_{3}\right)_{3}$ and EDTA in order to obtain new information about this reaction. Analysis of the spectra showed that only very small fraction of intermediates may be present in solution during the course of the reaction. The reaction scheme was established and according to it calculations based on a simplified model were carried out. Literature data for constants were used if known, otherwise, adjusted values of their sound estimates were applied. Reasonable agreement of the model calculations with the experimental data was obtained for $\mathrm{pH}$ values 3.8 and 4.5 but the model failed to reproduce measured rate of reaction at $\mathrm{pH} 5.5$, probably due to the use of the oversimplified model.
\end{abstract}

Keywords: Hexaaquachromium(III) ion; EDTA; [Cr(EDTA)]; UV/Vis spectrophotometry; reaction mechanism; chemical kinetics.

\section{Introduction}

The mechanism of the reaction between $\mathrm{Cr}^{3+}$ ion and disodium salt of ethylenediaminetetraacetic acid (EDTA) yielding coordinative compound $[\mathrm{Cr}(\mathrm{EDTA})]^{-}$was for the first time published in the era of pioneering work of modern coordination chemistry six decades ago by Hamm. ${ }^{1}$ At that time the lack of reliable analytical methods did not allow identification of all species involved in the reaction, there were no automated instruments to observe the progress of reaction, and the chemistry of chromium(III) was considerably less understood than nowadays. Considering that the product of this reaction absorbs visible light much more strongly than the reactants, absorbance of light at $545 \mathrm{~nm}$ was chosen for monitoring concentration of the product during the course of the reaction. Based on these results and on prior interpretation of mechanism of the reaction between $\mathrm{Cr}^{3+}$ ion and oxalate ${ }^{2}$ a mechanism involving rather quick formation of intermediate B by displacement of one water molecule in hexaaquachromium ion by EDTA ligand $(\mathrm{Y})$

$$
\left[\mathrm{Cr}\left(\mathrm{H}_{2} \mathrm{O}\right)_{6}\right]^{3+}+\mathrm{H}_{2} \mathrm{Y}^{2-} \rightarrow \mathrm{B}
$$

was postulated. In the next (equilibrium) step hydrogen ion was assumed to dissociate from the intermediate

$$
\mathrm{B} \leftrightarrow \mathrm{B}^{\prime}+\mathrm{H}^{+}
$$

what was supposed to be followed by the slow step in which chelate ring structure $\mathrm{C}$ is formed:

$$
\mathrm{B}^{\prime} \rightarrow \mathrm{C}
$$

The reaction was identified to be of the first order with respect to $\mathrm{Cr}^{3+}$, inverse first order on the hydrogen ion concentration, and to be independent of the concentration of the EDTA ligand.

An appropriate reaction rate and the possibility of a rather simple monitoring of the reaction progress using UV/Vis spectrophotometers were reasons why this reaction was, using slightly simplified mechanism, chosen as 
a suitable experiment for introducing undergraduate students into the world of chemical kinetics. ${ }^{3}$

In the beginning of 70's two papers of GéherGlücklich and Beck appeared where some objections against Hamm's mechanism were expressed. ${ }^{4,5}$ In the first and more important of both publications it was shown that the reaction rate is not independent of ligand concentration when EDTA is not present in large excess. This finding led to the conclusion that the rate-determining step is not the chelation step but rather entry of the EDTA ligand into the inner sphere of $\left[\mathrm{Cr}\left(\mathrm{H}_{2} \mathrm{O}\right)_{6}\right]^{3+}$ ion. Unfortunately, the study as well as three similar critical studies of that time published by Soviet authors ${ }^{6-8}$ in Zhurnal fizicheskoi khimii have been overlooked by Western scientists.

Contemporarily, studies of reaction mechanisms of chromium(III) ion with other (mainly unidentate) ligands were carrying out. Very important conclusion coming from those works was that the entry of the ligand into the inner sphere of a complex is far more rapid when chromium(III) ion is in the form of pentaaquahydroxochromium(III) ion, $\left[\mathrm{Cr}\left(\mathrm{H}_{2} \mathrm{O}\right)_{5}(\mathrm{OH})\right]^{2+}$, than in the case of hexaaquachromium(III) ion, $\left[\mathrm{Cr}\left(\mathrm{H}_{2} \mathrm{O}\right)_{6}\right]^{3+9}$.

Later on, in 80's, a significant advance was made in the chromium(III) chemistry by proper identification of some chromium(III) compounds. Up to that time kinetic studies of Cr(III)-EDTA complex were mainly based on erroneous identifications of the final product, dating back to 40 's. ${ }^{10,11}$ Identity of $\mathrm{Cr}$ (III)-EDTA complex in aqueous solutions as being sexidentate complex $[\mathrm{Cr}(\mathrm{EDTA})]^{-}$in the range of $\mathrm{pH}$ values between 3.5 and 6.5, was first confirmed by Wheeler and Legg ${ }^{12}$ using NMR spectroscopy. Two years later the same conclusion was made also by Kanamori and Kawai using Raman spectroscopy. ${ }^{13}$ In that time, the structure of [Cr(EDTA) $]^{-}$ion itself was unambiguously confirmed also by crystallography. ${ }^{14}$

In the light of all these new comprehensions, insisting on the originally proposed mechanism cannot be justified. While new facts were recognized in e.g. study of complex formation between chromium(III) and ethylenediamine-N, $\mathrm{N}^{\prime}$-diacetic acid ${ }^{15}$ it is noteworthy that original mechanism of formation of $\mathrm{Cr}$ (III)-EDTA complex with all of its deficiencies is still found present in some chemical kinetics textbooks ${ }^{16}$ as well as in a recent review articles from the field of coordination chemistry. ${ }^{17}$ It is the aim of this work to present experimental results showing that the premises used in the originally presented mechanism ${ }^{1}$ are erroneous and that the results of the here presented study support the basic premises of one of revised mechanisms. ${ }^{4}$ In this work, we will focus on reactions and mechanism that are possible in aqueous solutions in the $\mathrm{pH}$ range between 3.8 and 5.5 where chemical kinetics of this system is usually studied.

As an important new contribution to the understanding of this reaction, it will be shown that only small amount of intermediates are present during reaction and that $\mathrm{pH}$ value of a reaction mixture is changing considerably during the reaction. Experimental data describing change of the product concentration with time will be for the first time supplemented by the model calculations based on recent chromium(III) chemistry comprehension and exploiting literature data describing equilibria in $\mathrm{Cr}^{3+}$ and EDTA aqueous solutions.

\section{Experimental}

\section{1. Chemicals}

In experiments chromium(III) nitrate nonahydrate $\mathrm{Cr}\left(\mathrm{NO}_{3}\right)_{3} \cdot 9 \mathrm{H}_{2} \mathrm{O}$ (p.a, Riedel-de Haën, Germany) was used as a source of chromium(III) ions. Fresh aqueous solution of $\mathrm{Cr}\left(\mathrm{NO}_{3}\right)_{3}$ with concentration of $0.12 \mathrm{M}$ was prepared daily by dissolving weighed mass of $\mathrm{Cr}\left(\mathrm{NO}_{3}\right)_{3}$. $9 \mathrm{H}_{2} \mathrm{O}$ in triple distilled water to obtain $25.00 \mathrm{~mL}$ aqueous solution of given concentration.

For preparation of $0.15 \mathrm{M}$ aqueous solutions of sodium salt of ethylenediaminetetraacetic acid (EDTA) having selected $\mathrm{pH}$ values $(3.8,4.5$, and 5.5) disodium salt of EDTA (Aldrich, USA) was dissolved in a slightly less water amount as needed for preparation of the solution with the given $\mathrm{pH}$ value and concentration. Then, by addition of $1 \mathrm{M}$ solution of $\mathrm{HNO}_{3}$ (prepared from the concentrated solution of $\mathrm{HNO}_{3}$, p.a., Kemika, Croatia) or $1 \mathrm{M}$ $\mathrm{NaOH}$ (prepared from $\mathrm{NaOH}$ pellets, p.a., Merck, Germany) the desired $\mathrm{pH}$ value of EDTA solution was set and appropriate amount of water was added to achieve the chosen concentration.

Solution of 5.0 M sodium nitrate, used for keeping constant ionic strength of the solution during course of the reaction, was prepared by weighing solid $\mathrm{NaNO}_{3}$ (p.a., Merck, Germany) and dissolving this amount of the solute with triple distilled water in $50 \mathrm{~mL}$ volumetric flask to obtain the desired concentration.

\section{2. Instrumental}

For measuring $\mathrm{pH}$ values of solutions we used $\mathrm{pH}$ combination electrode with double junction (Metrohm, Switzerland). As the bridge electrolyte solution in the electrode (in order to avoid contamination of measured solutions with $\mathrm{Cl}^{-}$ions) $3.0 \mathrm{M} \mathrm{NaNO}_{3}$ solution was used. The potential difference between the glass and the reference electrode was measured with $\mathrm{pH}$ meter type 781 (Metrohm, Switzerland). Calibration of the $\mathrm{pH}$ combination electrode was carried out daily at $25{ }^{\circ} \mathrm{C}$ with two buffers (having $\mathrm{pH}$ values of 4.006 and 6.865). The practical slope of the electrode was every time almost identical to the theoretical one.

Absorption spectra in ultraviolet (UV) and visible (Vis) light spectral range were recorded at $25.0{ }^{\circ} \mathrm{C}$ using Cary 100 double beam instrument (Varian, USA). Solutions were measured in quartz cuvettes with light path of 
$1.00 \mathrm{~cm}$. The measured absorbance was corrected for absorbance of light in the cuvette and in the solvent (water or aqueous solution of $\mathrm{NaNO}_{3}$ ).

\section{3. Spectrophotometric Determination of Concentration of the Product}

Concentration of the reaction product, [Cr(EDTA) $]^{-}$, was monitored by measuring absorbance at $545 \mathrm{~nm}, A_{545}$. From the absorbance $A_{545}(t)$ measured in the cuvette with the reaction mixture at the time $t$, the absorbance $A_{545}(t=$ $0)$ measured in the solution containing $\mathrm{Cr}\left(\mathrm{NO}_{3}\right)_{3}$ and Na$\mathrm{NO}_{3}$ of the same concentration as used in the reaction mixture, was subtracted (absorption of light at $545 \mathrm{~nm}$ due to presence of EDTA can be neglected). This value was divided by the difference of absorbance $A_{545}(t=\infty)$ in the reaction mixture measured at the end of the reaction and absorbance $A_{545}(t=0)$. The obtained value was multiplied by the total concentration of $\mathrm{Cr}(\mathrm{III})$ ions, $C_{\mathrm{Cr}^{3} \text {-total }}$, present in the solution (in the experiments presented here concentration of EDTA ligand was always notably higher than the concentration of $\mathrm{Cr}(\mathrm{III})$ ions) to obtain [Cr(EDTA) $]^{-}$ concentration at the given time $t$ :

$$
c_{[\mathrm{Cr}(\mathrm{EDTA})]^{-}}(t)=\frac{A_{545}(t)-A_{545}(t=0)}{A_{545}(t=\infty)-A_{545}(t=0)} \cdot c_{\mathrm{Cr}^{3 *} \text {-total }}
$$

\section{Results and Discussion}

\section{1. Proposed Mechanism}

In aqueous solutions of $\mathrm{Cr}\left(\mathrm{NO}_{3}\right)_{3}$ chromium(III) ion can be found in numerous forms, both mono- and polynuclear, depending on $\mathrm{pH}$ value of the solution and on the age of the prepared solution. Although aqueous chemistry of chromium(III) ion is an object of intensive studies for decades ${ }^{18,19}$ it is, due to multiple equilibria existing in such solutions, difficult to quantitatively encompass relations among these species. Therefore, we will consider here very simplified equilibrium, where only mononuclear hexaaquachromium(III), $\left[\mathrm{Cr}\left(\mathrm{H}_{2} \mathrm{O}\right)_{6}\right]^{3+}$, and pentaaquahydroxochromium(III), $\left[\mathrm{Cr}\left(\mathrm{H}_{2} \mathrm{O}\right)_{5}(\mathrm{OH})\right]^{2+}$, ions are supposed to exist in freshly prepared weakly acidic aqueous solutions:

$$
\left[\mathrm{Cr}\left(\mathrm{H}_{2} \mathrm{O}\right)_{6}\right]^{3+} \stackrel{K}{\longleftrightarrow}\left[\mathrm{Cr}\left(\mathrm{H}_{2} \mathrm{O}\right)_{5}(\mathrm{OH})\right]^{2+}+\mathrm{H}^{+}
$$

The equilibrium constant $K$, determining the ratio between the concentrations of both species, has the value ${ }^{17}$ $K=1.0 \cdot 10^{-4}$ at $25^{\circ} \mathrm{C}$, implying thus that concentration of both species is approximately equal at $\mathrm{pH}=4$. It is further known that pentaaquahydroxochromium(III) ions are more labile than hexaaquachromium(III) ions. While water exchange rate constant on $\left[\mathrm{Cr}\left(\mathrm{H}_{2} \mathrm{O}\right)_{6}\right]^{3+}$ is $2.4 \cdot 10^{-6} \mathrm{~s}^{-1}$ it is 75 times greater on $\left[\mathrm{Cr}\left(\mathrm{H}_{2} \mathrm{O}\right)_{5}(\mathrm{OH})\right]^{2+}$, i.e. $1.8 \cdot 10^{-4} \mathrm{~s}^{-1}$ (both data are given for $\left.25^{\circ} \mathrm{C}\right) .{ }^{17}$ Therefore, it may be expected that the overall rate of reaction will increase by augmenting $\mathrm{pH}$ value due to the greater concentration of $\left[\mathrm{Cr}\left(\mathrm{H}_{2} \mathrm{O}\right)_{5}(\mathrm{OH})\right]^{2+}$ ions present in less acidic solutions. In order to avoid long notations for hexaaquachromium(III) and pentaaquahydroxochromium(III) ions when they are not necessary, in further text $\left[\mathrm{Cr}\left(\mathrm{H}_{2} \mathrm{O}\right)_{6}\right]^{3+}$ and $\left[\mathrm{Cr}\left(\mathrm{H}_{2} \mathrm{O}\right)_{5}(\mathrm{OH})\right]^{2+}$ ions will be hereafter denoted as $[\mathrm{Cr}]^{3+}$ and $[\mathrm{Cr}(\mathrm{OH})]^{2+}$, respectively.

Similarly as it is valid for chromium(III) ion also the charge of EDTA species depends on pH value of the solution. In the widest meaning, EDTA can be regarded as a hexaprotic system: four protons are located on four carboxylic groups while the remaining two can reside on two nitrogen atoms when solutions are strongly acidic. In the $\mathrm{pH}$ range between 3.5 and 5.5 the predominant species is $\mathrm{H}_{2}$ EDTA $^{2-}$, while up to approximately $12 \%$ of total EDTA concentration is in the form of $\mathrm{H}_{3} \mathrm{EDTA}^{-}$at $\mathrm{pH} 3.8$ and around $20 \%$ in the form of HEDTA ${ }^{3-}$ at $\mathrm{pH} 5.5$. $^{4}$

Further, taking into account the lifetime of water molecules inside the primary shell of $\mathrm{Cr}^{3+}$ ion (which is of order of several hours at room temperature) as well as attractive electrostatic forces between oppositely charged $[\mathrm{Cr}]^{3+}$ and $[\mathrm{Cr}(\mathrm{OH})]^{2+}$ ions on one side, and negatively charged EDTA ions on the other side, occurrence of preassociated reactant pairs in solutions containing $\mathrm{Cr}(\mathrm{III})$ and EDTA ions is expected. ${ }^{17}$ Therefore, according to speciation diagrams of chromium and EDTA species (outersphere) ion pairs $[\mathrm{Cr}]^{3+} \cdot \mathrm{H}_{3} \mathrm{EDTA}^{-},[\mathrm{Cr}]^{3+} \cdot \mathrm{H}_{2} \mathrm{EDTA}^{2-}$, $[\mathrm{Cr}]^{3+} \cdot \mathrm{HEDTA}^{3-},[\mathrm{Cr}(\mathrm{OH})]^{2+} \cdot \mathrm{H}_{3} \mathrm{EDTA}^{-},[\mathrm{Cr}(\mathrm{OH})]^{2+}$. $\mathrm{H}_{2} \mathrm{EDTA}^{2-}$, and $[\mathrm{Cr}(\mathrm{OH})]^{2+} \cdot \mathrm{HEDTA}^{3-}$ are predominantly expected. Their relative amounts, of course, strongly depend on $\mathrm{pH}$ value of the solution. Contrary to assumption where $\left[\mathrm{H}^{+}\right]$dependence on the rate of reaction is seen as an argument that the deprotonated 3+/3- reactant pair $[\mathrm{Cr}]^{3+} \cdot$ HEDTA $^{3-}$ is the actual reacting species, it is here assumed that in principle all these outer-sphere complexes can be converted into inner-sphere complexes. The rate constant of these conversions/reactions depends on the fact whether chromium(III) ion is in the form of $[\mathrm{Cr}$ $\left.\left(\mathrm{H}_{2} \mathrm{O}\right)_{6}\right]^{3+}$ or more labile (i.e. reactive) $\left[\mathrm{Cr}\left(\mathrm{H}_{2} \mathrm{O}\right)_{5}(\mathrm{OH})\right]^{2+}$ species. In principle, one has to allow exchange of protons between chromium(III) ion and EDTA ligand forming an ion pair. Consequently, due to proton ambiguity there should exist some kind of equilibrium among outer-sphere complexes bearing the same net charge (e.g. $[\mathrm{Cr}]^{3+}$. $\mathrm{H}_{2}$ EDTA $^{2-}$ and $[\mathrm{Cr}(\mathrm{OH})]^{2+} \cdot \mathrm{H}_{3}$ EDTA $\left.^{-}\right)$.

The rate determining step of the reaction between $\mathrm{Cr}^{3+}$ ions and EDTA ligand is presumed to be the release of the first molecule of water ${ }^{20}$ from $\left[\mathrm{Cr}\left(\mathrm{H}_{2} \mathrm{O}\right)_{6}\right]^{3+}$ or $\left[\mathrm{Cr}\left(\mathrm{H}_{2} \mathrm{O}\right)_{5}(\mathrm{OH})\right]^{2+}$ ion through interchange $(\mathbf{I})$ mechanism. Moreover, considering that the experimental volume of activation is negative for $\mathrm{Cr}^{3+}$ ion, the mechanism is probably of the associative interchange $\left(\mathbf{I}_{\mathbf{A}}\right)$ nature what means that the rate of substitution of water molecule by the ligand may be considerably different (either lower or greater) than the rate of the water molecule exchange. ${ }^{17}$ 
The rate of conversion of outer-sphere into inner-sphere complexes may therefore depend substantially on the ligand.

In the last step (which is actually series of several quick steps that are indiscernible one from another by today's techniques), chromium(III) ion in which one molecule of water is replaced by the incoming EDTA ligand, is transformed into [Cr(EDTA) $]^{-}$complex. Hypothesis that speaks in favour of quick release of remaining water molecules is partially supported by the statement of Eigen and Wilkins ".. the coordinated water is apparently weakened by having several charged donor atoms also attached to the metal (-e.g., $\mathrm{CN}^{-}$or EDTA ${ }^{4-}$ ), or even only one hydroxide group. “21

Above presumed mechanism of the reaction between $\mathrm{Cr}^{3+}$ and EDTA ions is graphically represented in Figure 1 .

\section{2. Detection of the Presence of Eventual Intermediates}

In order to detect ${ }^{22}$ possible intermediates, present in quantities that exceed approximately $1 \%$ of the total chromium quantity, we presupposed that formation of the outer-sphere complex does not change the absorption spectrum of chromium(III) ions to the extent that could be observed by UV/Vis spectrophotometer. On the other side, UV/Vis absorption spectra of inner-sphere complexes of chromium(III) ions depend both on the kind on the ligand and the number of the ligands of given species. Although this latter statement might not be always true, it is valid in most of the cases. For example, after isolation of malonatopentaaquochromium(III) (containing monodentatemalonate), malonatotetraaquochromium(III) (containing chelating malonate), and hexaaquachromium(III) ions Olson and Behnke ${ }^{23}$ measured their UV/Vis absorption spectra. All three spectra show two distinct absorbance bands (Figure 1 in Reference 23), differing among these compounds slightly in the wavelength of absorption maxima (one maximum at $\approx 410 \mathrm{~nm}$ and the second at $\approx 570 \mathrm{~nm}$ ). It is important to mention that the intensity of both absorption bands notably increases with the diminishing number of water molecules, being part of the inner-sphere complex, and that due to the changing ratio between intensity of both absorption bands UV/Vis absorption spectrum of malonatopentaaquochromium(III) ion cannot be reproduced as a linear combination of malonatotetraaquochromium(III) and hexaaquachromium(III) ions. Similarly, also the spectrum of $0.006 \mathrm{M} \mathrm{Cr}\left(\mathrm{NO}_{3}\right)_{3}$ aqueous solution $(\mathrm{pH}=3.22)$ is changed when to this solution concentrated $\mathrm{NaOH}$ solution is added. Upon stepwise addition of $\mathrm{NaOH}$, the intensity of the original spectrum increases. The trend in changing the ratio of intensity of absorption bands is now different from the case of malonatopentaaquochromium(III) ion and malonatotetraaquochromium(III) ion - increase of the absorption band at $430-440 \mathrm{~nm}$ is greater than the increase of the absorption band at $\approx 580 \mathrm{~nm}$ (Figure 2).

As it was already said, there exist numerous chromium(III) ionic species at $\mathrm{pH}$ values around 4 . The change of spectra in Figure 2 when $\mathrm{pH}$ is increased from 3.22 to 5.38 therefore strictly speaking cannot be attributed ${ }^{18,19,24}$ solely to transition from $\left[\mathrm{Cr}\left(\mathrm{H}_{2} \mathrm{O}\right)_{6}\right]^{3+}$ to $\left[\mathrm{Cr}\left(\mathrm{H}_{2} \mathrm{O}\right)_{5}(\mathrm{OH})\right]^{2+}$ but includes most probably also contribution from other species (presence of $\left[\mathrm{Cr}\left(\mathrm{H}_{2} \mathrm{O}\right)_{4}(\mathrm{OH})_{2}\right]^{+}$ is probable ${ }^{4}$ at $\mathrm{pH}$ values over 4$)$. In order to avoid excessive complexity of modelling the reaction scheme we will simplify it and accept here the widespread view to this

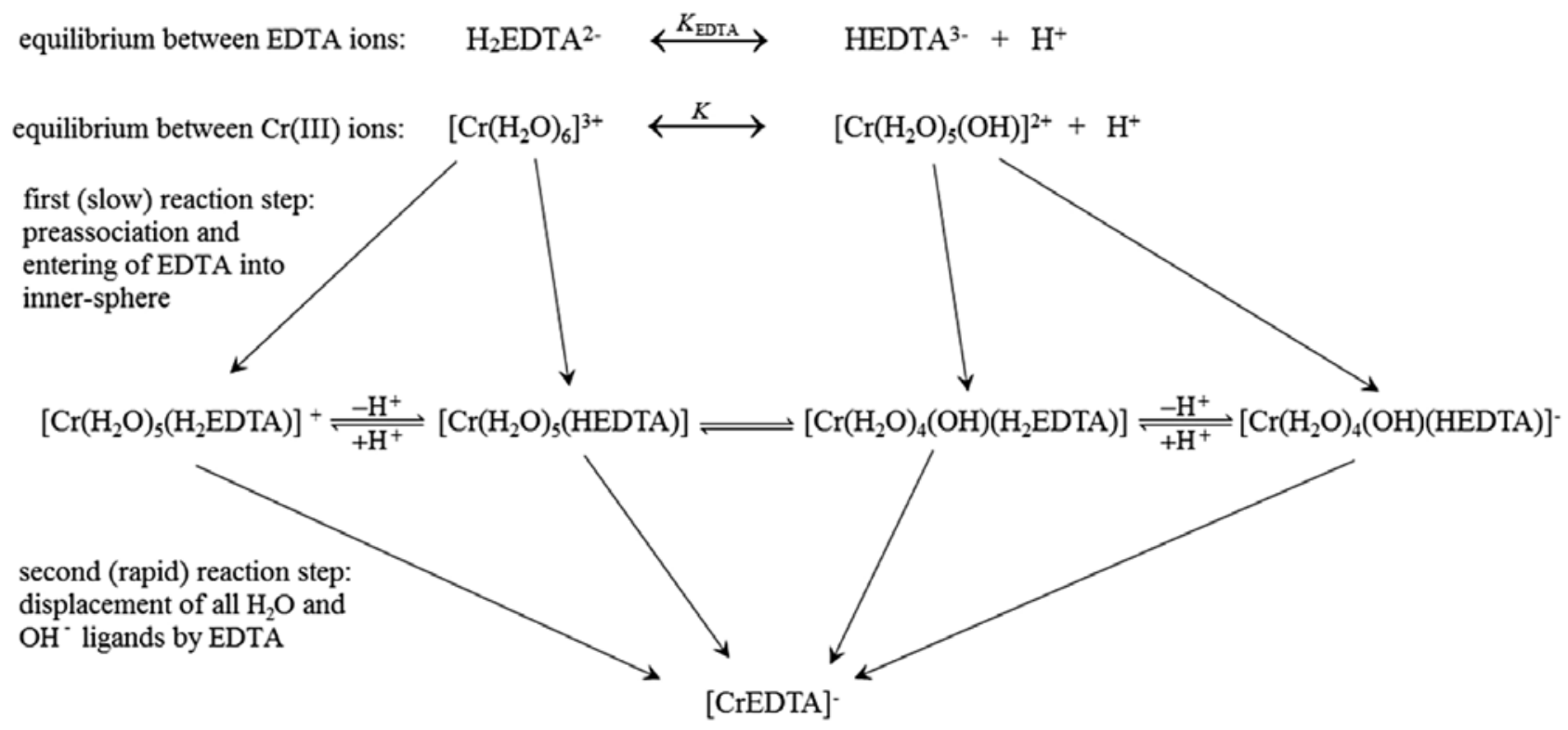

Fig. 1. Simplified (see the main text) assumed reaction mechanism for the reaction between $\mathrm{Cr}$ (III) and EDTA ions. 


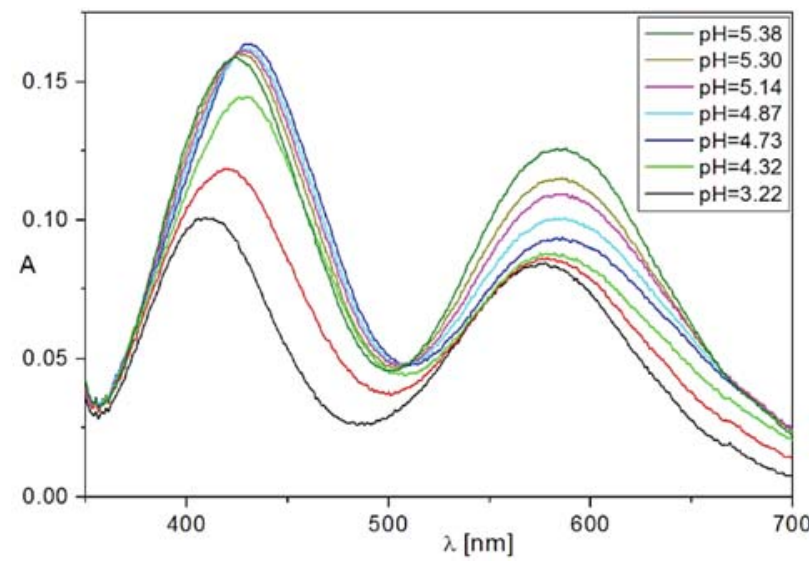

Fig. 2. Change of the absorption spectra of $0.0060 \mathrm{M} \mathrm{Cr}\left(\mathrm{NO}_{3}\right)_{3}$ aqueous solution upon addition of concentrated $\mathrm{NaOH}$ solution. When $\mathrm{pH}$ value was increased over $\mathrm{pH}=5.5$ precipitation took place.

equilibrium where only species $\left[\mathrm{Cr}\left(\mathrm{H}_{2} \mathrm{O}\right)_{6}\right]^{3+}$ and $\left[\mathrm{Cr}\left(\mathrm{H}_{2} \mathrm{O}\right)_{5}(\mathrm{OH})\right]^{2+}$ are present.

For assigning identity of the final product of the reaction we will rely on the comparison of recorded spectrum of the solution in which the reaction was completed (Figure 3) with the data of Wheeler and $\mathrm{Leg}^{12}$ and Hamm $^{1}$.

The reaction was carried out with the following initial concentrations of reactants: $0.0060 \mathrm{M} \mathrm{Cr}\left(\mathrm{NO}_{3}\right)_{3}$, $0.095 \mathrm{M}$ EDTA $(\mathrm{pH}=5.5)$, and $1 \mathrm{M} \mathrm{NaNO}_{3}$. In order to assure completion of the reaction, the reaction mixture was heated to $85^{\circ} \mathrm{C}$ for one hour after the end of the experiment, and then cooled to $25{ }^{\circ} \mathrm{C}$ to record the spectrum. Wavelengths of both absorption maxima $(391 \mathrm{~nm}, 541$ $\mathrm{nm}$ ) in the final solution (without added $\mathrm{NaOH}$ ) matched exactly to the mentioned literature data, reported for weakly acidic solution in which predominant species is $[\mathrm{Cr}(\text { EDTA })]^{-}$. Moreover, also the calculated molar absorp-

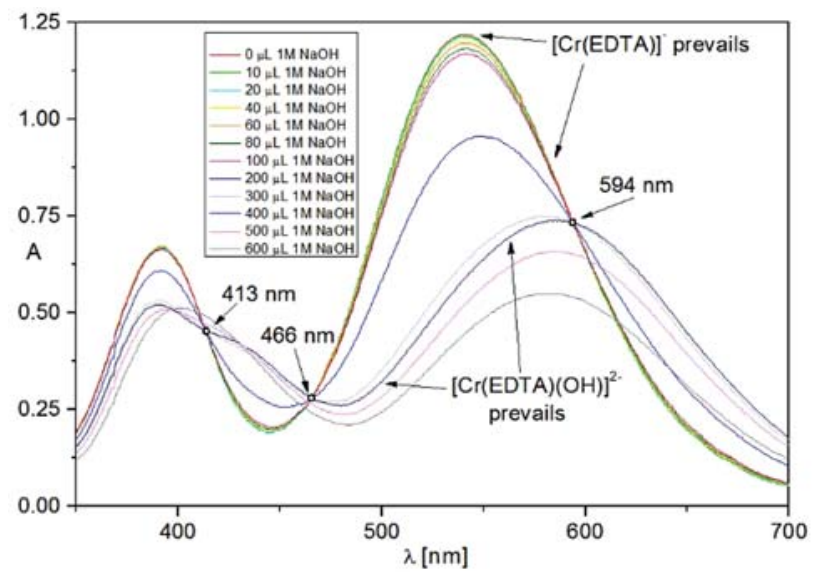

Fig. 3. Evolution of the absorption spectra of the final products of reaction between $\mathrm{Cr}(\mathrm{III})$ ions and EDTA upon stepwise addition of $1 \mathrm{M} \mathrm{NaOH}$ solution. For details about the reaction, see text. tion coefficient at $541 \mathrm{~nm}\left(\varepsilon_{541}=202.5 \mathrm{dm}^{3} \mathrm{~mol}^{-1} \mathrm{~cm}^{-1}\right)$ was in line with the reported values. ${ }^{1,12}$ When we added 1 $\mathrm{M} \mathrm{NaOH}$, the solution became slightly alkaline. As a result, wavelength of the second maximum changed to the value close to $581 \mathrm{~nm}$, again in full agreement with the literature data, reported for $[\mathrm{Cr}(\mathrm{EDTA})(\mathrm{OH})]^{2-}$.

During stepwise addition of $\mathrm{NaOH}$ which provoked transition of $[\mathrm{Cr}(\mathrm{EDTA})]^{-}$to $[\mathrm{Cr}(\mathrm{EDTA})(\mathrm{OH})]^{2-}$ three isosbestic points were detected: 413, 466, and $594 \mathrm{~nm}$ (Figure 3). This observation is similar to the one of Anis, who found ${ }^{15}$ isosbestic points at 415,490 , and $585 \mathrm{~nm}$ after increasing $\mathrm{pH}$ value in the solution of the reaction product, obtained during the reaction between $\mathrm{CrCl}_{3}$ and ethylenediamine-N,N'-diacetic acid. Moreover, in another study ${ }^{25}$ of Anis it was noted, that also addition of $\mathrm{NaOH}$ to the solution of final products of reaction between $\mathrm{Cr}$ (III) ions and N-(2-hydroxyethyl)ethylenediamine-N,N',N'triacetic acid (denoted as $\mathrm{TOH})$, i.e. $\left[\mathrm{Cr}(\mathrm{TOH})\left(\mathrm{H}_{2} \mathrm{O}\right)\right]$ and $[\mathrm{Cr}(\mathrm{TOH})(\mathrm{OH})]^{-}$, provokes appearance of three isosbestic points at 406,475 , and $570 \mathrm{~nm}$.

Obviously, absorption spectra are in the case of the reaction between $\mathrm{Cr}\left(\mathrm{NO}_{3}\right)_{3}$ and EDTA rather sensitive indicators for the presence of various species in the solution. Hence, all absorption spectra, recorded during the course of this reaction, should be reproduced by the linear combination of the starting and the final spectrum, if the overall reaction is composed of first (slow) step of entering of EDTA molecule into the inner-sphere complex with $\left[\mathrm{Cr}\left(\mathrm{H}_{2} \mathrm{O}\right)_{6}\right]^{3+}$ or $\left[\mathrm{Cr}\left(\mathrm{H}_{2} \mathrm{O}\right)_{5}(\mathrm{OH})\right]^{2+}$ ion and a rapid completion of the reaction in the second step. Such a reaction mechanism would allow presence of only minimal concentrations of intermediates and thus minimal contribu-

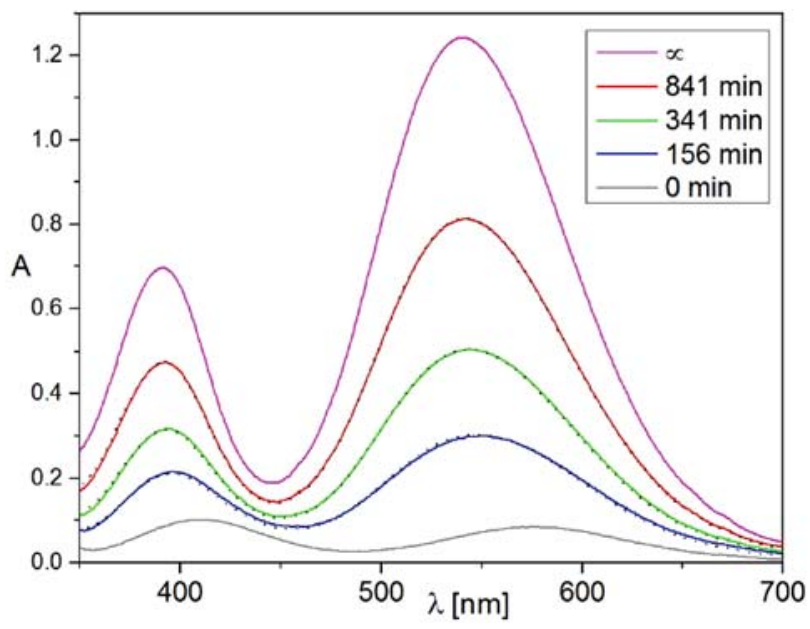

Fig. 4. Evolution of the absorption spectra in $1.0 \mathrm{M} \mathrm{NaNO}_{3}$ solution, containing $\mathrm{Cr}\left(\mathrm{NO}_{3}\right)_{3}$ and EDTA salt as reacting species. Initial concentrations of reactants were $6.0 \cdot 10^{-3} \mathrm{~mol} / \mathrm{dm}^{3}\left(\mathrm{Cr}\left(\mathrm{NO}_{3}\right)_{3}\right)$ and $0.095 \mathrm{~mol} / \mathrm{dm}^{3}$ (EDTA salt). Initial $\mathrm{pH}$ value was close to 3.8 (determined by the $\mathrm{pH}$ value of EDTA solution). The reaction was carried out at $25.0^{\circ} \mathrm{C}$. Black dotted lines at 156,341 , and 841 min represent linear combinations of the initial $(t=0 \mathrm{~min})$ and the final $(t$ $=\infty)$ spectrum. 
tion of absorption spectra of intermediates to the spectrum of the reaction mixture. Test of this hypothesis is shown in Figure 4.

As can be seen from Figure 4, spectra recorded at 156,341 , and 841 minute from the beginning of the reaction, carried out with initial concentrations $c_{\mathrm{Cr}(\mathrm{NO} 3) 3}=$ $6.0 \cdot 10^{-3} \mathrm{~mol} / \mathrm{dm}^{3}$ and $c_{\text {EDTA }}=0.095 \mathrm{~mol} / \mathrm{dm}^{3}(\mathrm{pH}=3.8)$, can be indeed very well reproduced by the linear combination of the spectra, recorded at $t=0$ and at $t=\infty$. Although in Figure 4 only the case of the reaction with initial EDTA pH value of 3.8 is shown, also spectra in the reaction mixtures with initial EDTA solutions having $\mathrm{pH}$ values of 4.5 and 5.5, recorded during the course of the reaction, can be described as a linear combination of the starting and the final spectrum.

The important conclusion, being evident from Figure 4 , is that reaction between $\mathrm{Cr}\left(\mathrm{NO}_{3}\right)_{3}$ and EDTA occurs without notable accumulation of intermediates (if we ignore presence of outer-sphere complexes). This supports here assumed reaction mechanism.

\section{3. An Attempt of Quantification of Constants in Reaction Mechanism}

It is well known that concordance of the order of reaction in given reactant, as it follows from the reaction mechanism, with the one experimentally obtained, does not guarantee that the assumed mechanism is correct. In this regard, duplication of experiments that have already been done by other authors and elucidation of order of reaction in a given reactant from the experimental data would tell nothing new. Instead, as an attempt of quantitative description the here presented mechanism is used. Namely, with the use of acidity constant $K$ covering equilibrium between concentrations of $\left[\mathrm{Cr}\left(\mathrm{H}_{2} \mathrm{O}\right)_{6}\right]^{3+}$ and $\left[\mathrm{Cr}\left(\mathrm{H}_{2} \mathrm{O}\right)_{5}(\mathrm{OH})\right]^{2+}$ species, and dissociation constant determining concentration ratio of $\mathrm{H}_{2}$ EDTA $^{2-}$ and HEDTA ${ }^{3-}$ ions, together with adjusted/estimated values of rate constants for partial reactions in reaction mechanism, the course of the reaction is modelled. The model used, elucidated from the reaction scheme presented in Figure 1 and slightly simplified, is described more in details in the Supporting Material for this paper. It has to be said, that preassociation of $\mathrm{Cr}(\mathrm{III})$ and EDTA ions to ion-pairs was not explicitly taken into account in the model but was incorporated into the rate of the partial reactions.

In this modelled reaction, evolution of $\mathrm{pH}$ value of the reaction mixture plays an important role because it determines the concentrations of $\left[\mathrm{Cr}\left(\mathrm{H}_{2} \mathrm{O}\right)_{6}\right]^{3+}$ and $[\mathrm{Cr}$ $\left.\left(\mathrm{H}_{2} \mathrm{O}\right)_{5}(\mathrm{OH})\right]^{2+}$ ions used in the model calculations. A brief remark that large excess of EDTA ligand does not guarantee constant $\mathrm{pH}$ value of the reaction mixture $\mathrm{du}-$ ring the reaction, was already given by Géher-Glücklich and Beck but the extent of $\mathrm{pH}$ change has never been shown. In order to include such an influence in the model

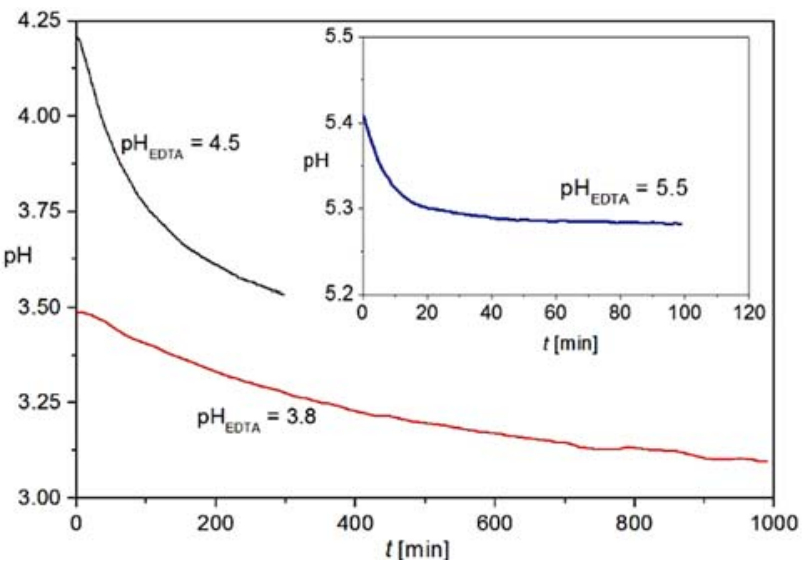

Fig. 5. Evolution of $\mathrm{pH}$ value during reaction between $\mathrm{Cr}\left(\mathrm{NO}_{3}\right)_{3}$ and EDTA, shown for reaction mixtures prepared from three EDTA solutions of different $\mathrm{pH}$ values $(3.8,4.5$, and 5.5). Due to a much shorter time scale the diagram for reaction with EDTA solution of $\mathrm{pH}=5.5$ is presented as an inset to the main diagram. The initial concentration of $\mathrm{Cr}\left(\mathrm{NO}_{3}\right)_{3}$ solution was $0.0060 \mathrm{M}$, EDTA $0.095 \mathrm{M}$, and $\mathrm{NaNO}_{3} 1.0 \mathrm{M}$. Reactions were carried out at $25^{\circ} \mathrm{C}$.

calculations, the $\mathrm{pH}$ value was monitored during course of the reactions (Figure 5).

As one can see, the $\mathrm{pH}$ value can be changed substantially during the reaction. The smallest decrease (for about $0.2 \mathrm{pH}$ unit) was observed when EDTA solution of $\mathrm{pH}=5.5$ was used as the reactant while in the remaining two cases ( $\mathrm{pH}=4.5$ and 3.8) the decline was much more pronounced (of order of $1 \mathrm{pH}$ unit). Such a change of $\mathrm{pH}$ value in the vicinity of $\mathrm{p} K$ value of $\mathrm{Cr}^{3+}$ ion considerably changes the ratio between concentrations of $\left[\mathrm{Cr}\left(\mathrm{H}_{2} \mathrm{O}\right)_{6}\right]^{3+}$ and $\left[\mathrm{Cr}\left(\mathrm{H}_{2} \mathrm{O}\right)_{5}(\mathrm{OH})\right]^{2+}$ ions and certainly has to be taken into account in model calculations. Results of the latter ones are presented below.

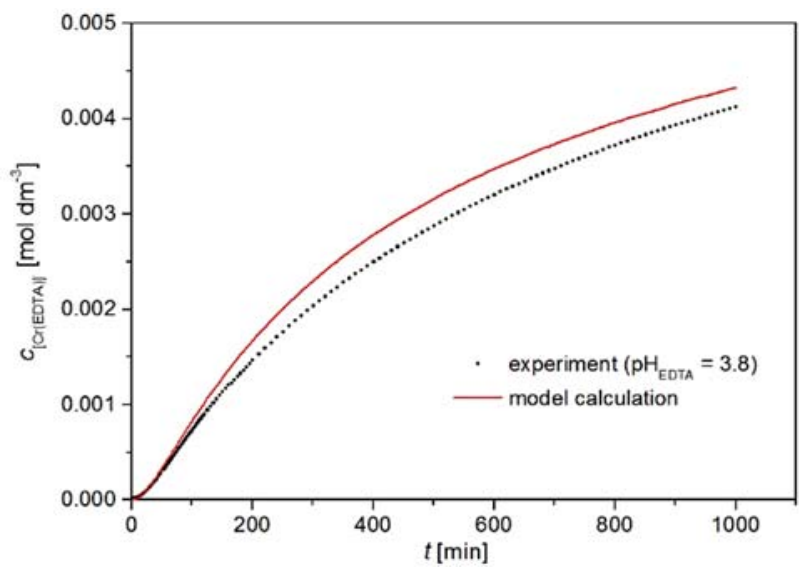

Fig. 6. Comparison of the results from the model calculated (red line) concentrations of reaction product (reaction at $\mathrm{pH}=3.8$ and $T=$ $25^{\circ} \mathrm{C}$ ) with the experimental data (dots) as a function of time. Initial concentration of $\mathrm{Cr}\left(\mathrm{NO}_{3}\right)_{3}$ was $0.0060 \mathrm{M}$, EDTA $0.095 \mathrm{M}(\mathrm{pH}$ = 3.8), and $\mathrm{NaNO}_{3} 1.0 \mathrm{M}$. See Supporting Material for description of the model. 
In Figure 5, an increase in the concentration of the reaction product $[\mathrm{Cr}(\mathrm{EDTA})]^{-}$with the course of the reaction, is presented. The dots represent experimental points, obtained with the help of spectrophotometer, while the solid line denotes the model prediction.

As can be deduced from the graph, a curve typical for a consecutive reaction having the first step considerably slower than the second one is obtained. Agreement between the model curve and experimental data $($ at $\mathrm{pH}=$ 3.8) is good but deteriorates with the increase of $\mathrm{pH}$ (Figures 7 and 8 ).

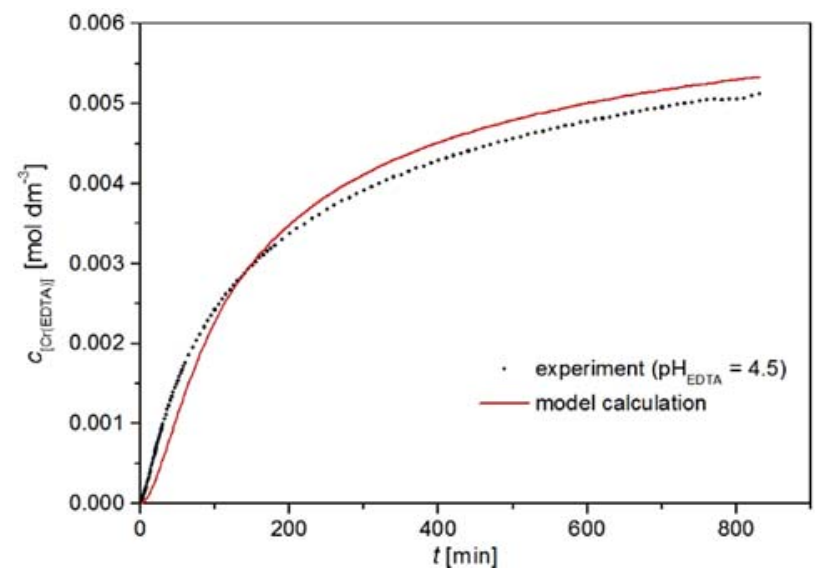

Fig. 7. Same as in Figure 6 but for $\mathrm{pH}=4.5$.

Judging from the comparison of experimental curves, shown in Figures 6 and 7, one can conclude that the reaction rate is accelerated predominantly in the first (rate-determining) step where the characteristic "lag" before the inflection point is shortened. This is even more notable in Figure 8.

As one can see from Figure 8, the experimental curve, when compared to curves at $\mathrm{pH} 3.8$ and 4.5, lost all the character of curves that are characteristic for reac-

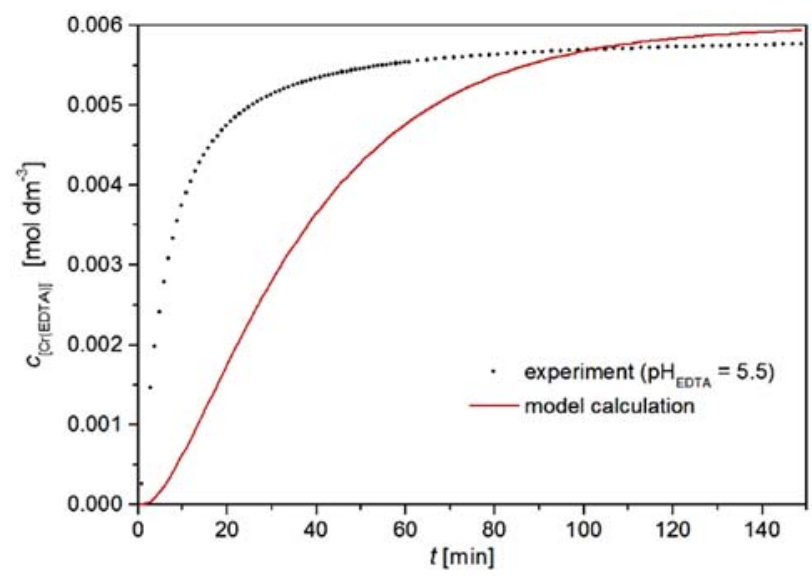

Fig. 8. Same as in Figure 6 but for $\mathrm{pH}=5.5$. tions being composed of two consecutive reactions. Considering that $\mathrm{pH}$ value is here rather high it is possible that a significant fraction of reactant $\mathrm{Cr}(\mathrm{III})$ ions is present in the form of $\left[\mathrm{Cr}\left(\mathrm{H}_{2} \mathrm{O}\right)_{4}(\mathrm{OH})_{2}\right]^{+}$ions ${ }^{4,27}$ and that the rate of entrance of EDTA ligand into the inner-sphere of (Cr(III) is (due to the presence of two $\mathrm{OH}^{-}$destabilising ligands $)^{17,21}$ even higher than in the case of $\left[\mathrm{Cr}\left(\mathrm{H}_{2} \mathrm{O}\right)_{5}(\mathrm{OH})\right]^{2+}$ ion. This probably means that the presented model calculations should be limited to the narrower $\mathrm{pH}$ range or that also the equilibrium between $\left[\mathrm{Cr}\left(\mathrm{H}_{2} \mathrm{O}\right)_{5}(\mathrm{OH})\right]^{2+}$ and $\left[\mathrm{Cr}\left(\mathrm{H}_{2} \mathrm{O}\right)_{4}(\mathrm{OH})_{2}\right]^{+}$species should be included into the reaction scheme. Unfortunately, no data about the rate constants for exchange of ligands in $\left[\mathrm{Cr}\left(\mathrm{H}_{2} \mathrm{O}\right)_{4}(\mathrm{OH})_{2}\right]^{+}$ion is available. Inclusion of such rate constant in the model calculation as a pure adjustable parameter would require also carrying out additional (and numerous) experiments, what is beyond the scope of this study.

\section{Conclusions}

By recording UV/Vis absorption spectra of aqueous solutions containing $\mathrm{Cr}(\mathrm{III})$ and EDTA ions it was shown that the spectra of the reaction mixture, obtained during the course of the reaction, can be described as a linear combination of the initial and final UV/Vis spectra. Having in mind that spectra of $\mathrm{Cr}(\mathrm{III})$ ion are ligand dependent that implies that no notable (estimated up to $1 \%$, probably even less) fraction of $\mathrm{Cr}$ (III) ions is in the form of intermediates during the course of the reaction.

Above finding supports here proposed reaction scheme, which takes into account the literature data on chromium(III) coordination chemistry. Ensuing from the proposed reaction scheme, model calculations were done and compared with the experimental data. With the use of adjustable rate constants that were within the range of values, found for other ligands, reasonable agreement between model calculations and experimental data was obtained at $\mathrm{pH} 3.8$ and 4.5 while the rate of reaction was strongly underestimated at $\mathrm{pH} 5.5$, most probably due to neglecting the presence of $\left[\mathrm{Cr}\left(\mathrm{H}_{2} \mathrm{O}\right)_{4}(\mathrm{OH})_{2}\right]^{+}$ions in the solution. These results show that the reaction mechanism of reaction between $\mathrm{Cr}(\mathrm{III})$ ions and EDTA is far more complex than presented in earlier studies. In order to achieve more detailed understanding of the reaction additional experimental data as well as establishing a more complex model that could be verified through comparison with the experimental data are needed.

\section{Acknowledgements}

Financial support by the Slovenian Research Agency through Grant No. P1-0201 is gratefully acknowledged. 


\section{References}

1. R. E. Hamm, J. Am. Chem. Soc. 1953, 75, 5670-5672. http://dx.doi.org/10.1021/ja01118a059

2. R. E. Hamm, R. E. Davis, J. Am. Chem. Soc. 1953, 75, 30853089. http://dx.doi.org/10.1021/ja01109a011

3. C. E. Hedrick, J. Chem. Educ. 1965, 42, 479-480. http://dx.doi.org/10.1021/ed042p479

4. J. Géher-Glücklich, M. T. Beck, Acta Chim. Acad. Scient. Hung. 1971, 70, 235-246.

5. J. Géher-Glücklich, M. T. Beck, Acta Chim. Acad. Scient. Hung. 1971, 70, 247-253.

6. B. S. Grigorev, Y. Y. Makarov-Zemlyansky, N. N. Pavlov, Zh. Fiz. Khim. 1974, 48, 1173-1176.

7. N. Y. Laptev, V. I. Kornev, L. B. Ionov, Zh. Fiz. Khim. 1976, 50, 1699-1702.

8. V. I. Kornev, S. L. Kharitonova, Zh. Fiz. Khim. 1976, 50, 1703-1706.

9. J. H. Espenson, Inorg. Chem. 1969, 8, 1554-1556. http://dx.doi.org/10.1021/ic50077a047

10. H. Brintzinger, H. Thiele, U. Müller, Z. Anorg. Allg. Chem. 1943, 251, 285-294. http://dx.doi.org/10.1002/zaac.19432510308

11. G. Schwarzenbach, W. Biedermann, Helv. Chim. Acta 1948, 31, 459-465. http://dx.doi.org/10.1002/hlca.19480310223

12. W. D. Wheeler, J. I. Legg, Inorg. Chem. 1984, 23, 3798- 3802. http://dx.doi.org/10.1021/ic00191a026

13. K. Kanamori, K. Kawai, Inorg. Chem. 1986, 25, 3711-3713. http://dx.doi.org/10.1021/ic00240a041

14. Y. Kushi, K. Morimasa, H. Yoneda 49th Annual Meeting of the Chemical Society of Japan, Tokyo, April 1984; Abstract No. 1 N31.
15. S. S. Anis, Mater. Chem. Phys. 2001, 72, 88-92. http://dx.doi.org/10.1016/S0254-0584(01)00318-2

16. M. R. Wright, An Introduction to Chemical Kinetics. J. Wiley \& Sons: Chichester: 2004; p. 351. http://dx.doi.org/10.1002/047009060X

17. D. T. Richens, Chem. Rev. 2005, 105, 1961-2002. http://dx.doi.org/10.1021/cr030705u

18. L. F. Rao, Z. C. Zhang, J. I. Friese, B. Ritherdon, S. B. Clark, N. J. Hess, D. Rai, J. Chem. Soc.-Dalton Trans. 2002, 267274. http://dx.doi.org/10.1039/b104154c

19. A. Drljaca, M. J. Hardie, C. L. Raston, L. Spiccia, Chem.Eur. J. 1999, 5, 2295-2299. http://dx.doi.org/10.1002/(SICI)1521-3765(19990802)5:8 <2295::AID-CHEM2295>3.0.CO;2-O

20. D. E. Bracken, H. W. Baldwin, Inorg. Chem. 1974, 13, 1325-1329. http://dx.doi.org/10.1021/ic50136a015

21. M. Eigen, R. G. Wilkins, Adv. Chem. Ser. 1965, 49, 55-80. http://dx.doi.org/10.1021/ba-1965-0049.ch003

22. R. Vafazadeh, S. Bidaki, Acta Chim. Slov. 2014, 61, 153- 160.

23. M. V. Olson, C. E. Behnke, Inorg. Chem. 1974, 13, 13291334. http://dx.doi.org/10.1021/ic50136a016

24. N. Torapava, A. Radkevich, D. Davydov, A. Titov, I. Persson, Inorg. Chem. 2009, 48, 10383-10388. http://dx.doi.org/10.1021/ic901539g

25. S. S. Anis, Transit. Met. Chem. 1999, 24, 152-155. http://dx.doi.org/10.1023/A:1006946430644

26. S. G. Hosseini, K. Gholivand, M. Khosravi, S. J. H. Toloti, H. M. Pandas, Acta Chim. Slov. 2013, 60, 228-236.

27. C. F. Baes, R. E. Messmer, The Hydrolysis of Cations. John Wiley\&Sons: New York, 1976.

\section{Povzetek}

Obstoječe razlage reakcijskega mehanizma šolske reakcije med $\mathrm{Cr}$ (III) ioni in etilendiamintetraocetno kislino (EDTA) niso skladne s sodobnimi znanji s področja koordinacijskih spojin kromovih(III) ionov. Potek reakcije med $\mathrm{Cr}\left(\mathrm{NO}_{3}\right)_{3}$ in EDTA smo spremljali spektrofotometrično s snemanjem absorpcijskega spektra v ultravijoličnem in vidnem področju. Analiza posnetih spektrov je pokazala, da je med potekom reakcije prisotnih le malo intermediatov, kar nasprotuje nekaterim obstoječim razlagam tega reakcijskega mehanizma. Izhajajoč iz te ugotovitve in upoštevajoč sodobna znanja smo predpostavili reakcijski mehanizem te reakcije. Na podlagi poenostavljenega reakcijskega mehanizma smo sestavili računski model poteka reakcije, ki je vseboval iz literature poznane konstante oziroma njihove smiselne ocene, če lete niso bile poznane. Napoved računskega modela se je dokaj dobro ujela z izmerjenimi vrednostmi pri pH 3,8 in 4,5, medtem ko je model odpovedal pri $\mathrm{pH}$-vrednosti 5,5. Neujemanje modela s poskusom v slednjem primeru pojasnjujemo z izbiro preveč poenostavljenega modela. 